\title{
Serum TLR2 and TLR4 levels in colorectal cancer and their association with systemic inflammatory markers, tumor characteristics, and disease outcome
}

\author{
Authors: \\ Anne Tuomisto ${ }^{\mathrm{b}}$; anne.tuomisto@oulu.fi \\ Sara A. Väyrynen ${ }^{\text {b.c }}$; sara.sajanti@oulu.fi \\ Juha P. Väyrynen ${ }^{\text {b,d }}$; juha.vayrynen@oulu.fi \\ Kai Klintrup ${ }^{\text {a }}$ kai.klintrup@oulu.fi \\ Pasi Ohtonen ; pasi.ohtonen@oulu.fi \\ Markus J. Mäkinen ${ }^{\text {b }}$ markus.makinen@oulu.fi \\ Jyrki Mäkelä*a; jyrki.makela@oulu.fi \\ Tuomo J. Karttunen*b; tuomo.karttunen@oulu.fi
}

Karoliina Paarnio ; karoliina.paarnio@me.com; tel. +358 400764976; fax: +358-08-3155318

*Equal contribution

a) Research Unit of Surgery, Anesthesia and Intensive Care, University of Oulu, POB 5000, 90014 Oulu,

Finland, and Department of Surgery, Oulu University Hospital, and Medical Research Center Oulu, POB 21, 90029 Oulu, Finland

b) Department of Pathology, Cancer and Translational Medicine Research Unit, University of Oulu, POB 5000, 90014 Oulu, Finland, and Oulu University Hospital and Medical Research Center Oulu, POB 21, 90029 Oulu,

Finland

c) Department of Medical Oncology, Dana-Farber Cancer Institute and Harvard Medical School, 450 Brookline Ave, Boston, MA, 02215, USA

d) Department of Oncologic Pathology, Dana-Farber Cancer Institute and Harvard Medical School, 450

Brookline Ave, Boston, MA 02215, USA

This article has been accepted for publication and undergone full peer review but has not been through the copyediting, typesetting, pagination and proofreading process, which may lead to differences between this version and the Version of Record. Please cite this article as doi: 10.1111/apm.12971

This article is protected by copyright. All rights reserved. 


\title{
Paarnio Karoliina, Tuomisto Anne, Väyrynen Sara A, Väyrynen Juha P, Klintrup Kai, Ohtonen Pasi, Mäkinen Markus J, Mäkelä Jyrki, Karttunen Tuomo J.
}

\section{Running head: Serum TLR2 and TLR4 levels in colorectal cancer and their association with systemic inflammatory markers, tumor characteristics, and disease outcome}

\section{Corresponding author:}

\author{
Karoliina Paarnio, Oulu University Hospital, Kajaanintie 50, 90220 Oulu, Finland \\ karoliina.paarnio@me.com \\ tel. +358 400764976; fax: +358-08-3155318
}

\section{Summary}

Toll-like receptors (TLRs) are involved in colorectal cancer (CRC) pathogenesis. However, the significance of serum TLR concentrations in CRC is unknown. We analyzed serum TLR2 and TLR4 concentrations with ELISA in preoperative samples from 118 patients with CRC and 88 matched controls. We also assessed tissue TLR expression with immunohistochemistry and by detecting serum determinants of systemic inflammation. Most participants (>70\%) had undetectable serum TLR2. The mean serum TLR4 levels were lower in patients than in controls ( $1.1 \mathrm{vs.} 1.8 \mathrm{ng} / \mathrm{ml}$; $\mathrm{p}=0.015$ ). Undetectable TLR4 was more common in stage I (39\%) than in stages II-IV (11\%, p<0.001). TLR2 or TLR4 expression in tumor cells did not correlate with serum levels, but abundant TLR2 expression in normal colon epithelium was associated with detectable serum TLR2 ( $\mathrm{p}=0.034)$. Undetectable serum TLR2 was linked to high modified Glasgow prognostic scores $(\mathrm{p}=0.010)$, high CRP levels $(\mathrm{p}=0.013)$, blood vessel invasion $(\mathrm{p}=0.013)$, and tended to be associated with worse 5 -year survival $(\mathrm{p}=0.052)$. In conclusion, serum TLR2 levels were inversely associated with systemic inflammation in patients with CRC. Moreover, serum TLR2 levels might depend more on normal colorectal mucosa contributions than on tumor tissue contributions. Further studies are required to assess the prognostic value of serum TLR2.

\section{Keywords}

Colorectal Cancer; Toll-like Receptor 2; Toll-like Receptor 4; Inflammation; Prognosis; ELISA

This article is protected by copyright. All rights reserved. 


\section{Introduction}

Colorectal cancer $(\mathrm{CRC})$ is the third most common malignancy in Europe and the US $(1,2)$. It is thought to develop through a stepwise accumulation of genetic and epigenetic alterations (3). Currently, intensive investigation has focused on how environmental factors and inflammation, in particular, affect CRC development and prognosis (4). Chronic inflammation is a known risk factor of different forms of cancer (5). Intensive immune cell infiltration in CRC specimens indicates a good prognosis $(6,7)$, but systemic inflammation is a significant determinant of a poor prognosis in CRC (8-10). Understanding the inflammatory component in the development and prognosis of tumors is important for creating new preventive and therapeutic methods.

Toll-like receptors (TLRs) recognize micro-organisms and endogenous ligands. Ligand binding initiates a signaling cascade that activates the inflammatory response $(11,12)$. In a previous study, we characterized TLR2 and TLR4 tissue expression in CRC and found downregulation of TLR4 and upregulation of TLR2 in tumor tissues compared to normal mucosa. In addition, low TLR4 expression at the invasive front in the proximal colon was associated with a poor prognosis and the presence of distant metastases (13).

Soluble TLRs are released from tissues and blood cells into the circulation, and their concentrations increase during infections and inflammatory conditions (14). Only a few studies have assessed serum TLR levels in malignancies. Reduced serum TLR9 concentrations have been detected in patients with breast cancer; indeed, low TLR9 levels were associated with disease progression and advanced stages (15). A recent study found that serum TLR4 was increased in non-small cell lung carcinoma, but the cellular origin was not studied (16). To our knowledge, no previous studies have investigated serum TLR concentrations in CRC.

In the present study, we aimed to gain insight into the cellular origin and other factors that contribute to serum TLR2 and TLR4 levels in CRC. We assessed serum TLR2 and TLR4 concentrations in 118 patients with CRC and 88 matched controls. We analyzed associations between serum TLRs and tumor and patient characteristics. We also analyzed TLR expression in tumor cells and normal colorectal mucosa. We determined whether serum TLR concentrations were associated with biomarkers of systemic inflammation, including C-reactive protein (CRP), and the modified Glasgow prognostic score (mGPS). Finally, we assessed the relationship between serum TLR2 and TLR4 levels and survival.

This article is protected by copyright. All rights reserved. 


\section{Materials and methods}

\section{Patients and controls}

We collected data prospectively from 149 patients newly diagnosed with CRC that underwent surgery in Oulu University Hospital between April 2006 and January 2010. Prior to entering the study, all patients provided signed informed consent to participate $(8,13)$. Control serum samples were collected from age- and sexmatched healthy individuals that had voluntarily donated blood (Finnish Red Cross, Oulu, Finland; n=36, age $<65$ years) and from patients that underwent cataract surgery (Oulu University Hospital; $n=52$, age $\geq 65$ years). In selecting subjects for the control group, we excluded individuals with other malignant diseases diagnosed prior to or at the time of sample collection (11). Other criteria for excluding samples from the blood donors included, e.g., acute infections; trauma or operations during the preceding four months; chronic diseases, such as coronary artery disease, stroke or cancer; and organ transplantation. Due to sampling arrangements, control serum samples were collected during the winter months. In contrast, patient samples were collected based on the timing of the operative treatment, because they were collected just prior to the surgery. Thus, patient samples were collected throughout the year. The Regional Ethics Committee of North Ostrobothnia Hospital District approved both the original study design and the follow-up study $(58 / 2005,184 / 2009,60 / 2012)$.

Clinical records were accessed to obtain clinical details and follow-up information for patients. Statistics Finland provided data on the time and cause of death. Preoperative CRC staging was based on whole body computed tomography (CT) scans. Local staging of rectal cancer was based on magnetic resonance imaging (MRI). Patients with rectal cancer in stage T3 or T4 received preoperative neoadjuvant irradiation or chemoradiation therapy $(n=31)$, and they were excluded from the final analysis to avoid potential confounding caused by preoperative treatment. Thus, a total of 118 patients were included in the final analyses. The TNM6 classification system (17) was used for staging, and the WHO2010 classification (18) was used for grading. Serrated adenocarcinomas were diagnosed according to WHO2010 criteria, as described by Mäkinen et al (18, 19). Blood vessel invasion was defined as the presence of tumor cells in vessels with a thick muscular wall or in vessels that contained red blood cells (20).

This article is protected by copyright. All rights reserved. 
We defined disease-free survival as the time interval between the primary operation and the detection of recurrence. The disease-free survival analysis was based on data for patients that received a curative primary operation and did not die from a cause other than CRC during the 5-year follow-up period (n=83 patients). Fiveyear overall survival analyses included all patients alive 5 years after the primary operation ( $\mathrm{n}=71$ patients).

\section{Serum TLR2 and TLR4 assays}

We performed enzyme-linked immunosorbent assays (ELISAs) to determine the quantities of TLR2 and TLR4 in serum samples from 118 patients with CRC and 88 age- and sex-matched controls. We used ELISA kits with human TLR2 antibody (Abcam, Cambridge, UK) and TLR4 antibody (MyBioSource, San Diego, USA), according to the manufacturer's instructions. Standards were provided in the kits, and they were included in every plate. The color intensities of the samples were measured with a Victor3 plate reader (PerkinElmer, Massachusetts, USA). All measurements were performed blinded to clinical data.

\section{Serum CRP and Glasgow prognostic score determinations}

We determined CRP (mg/l) and serum albumin (g/l) levels in preoperative blood samples from a previous study (8). The mGPS was evaluated as follows: Score $0=$ normal CRP and albumin values; score $1=$ only CRP was elevated $(>10 \mathrm{mg} / \mathrm{l})$; and score 2 = CRP was elevated $(>10 \mathrm{mg} / \mathrm{l})$ and albumin was low $(<35 \mathrm{~g} / \mathrm{l})$.

\section{Immunohistochemistry and assessment of TLR2 and TLR4 expression in tissues}

TLR2 and TLR4 immunohistochemistry was conducted and analyzed as previously described (13). We analyzed cancer specimens with tissue microarrays, and we analyzed whole sections of normal mucosa and lymph node metastasis samples mounted on slides (13). Two independent researchers (KP and SAV) analyzed TLR2 and TLR4 expression in a blinded manner. They separately assessed the intensity of the staining $(0=$ negative, $1=$ weak, $2=$ moderate, and $3=$ strong $)$ and the percentage of positively-stained cells $(0-100 \%)$ in the invasive tumor front, in the bulk of the tumor, in the normal mucosa, and in lymph node metastases, when present. The histoscore (0-300) for tissue samples was defined as the stain intensity score multiplied by the percentage of positive cells. To improve representations of tumor mass, the tumor bulk and front histoscores were multiplied by the largest diameter of the tumor, and the lymph node histoscore was multiplied by the number of metastatic lymph nodes.

This article is protected by copyright. All rights reserved. 


\section{Statistical analyses}

Summary statistics are expressed as the mean and standard deviation (SD) or the median and 25th -75 th percentile, unless stated otherwise. The Chi-square test or Fisher's exact test was used to analyze categorical data, and the Student's t-test was used for continuous data. We constructed receiver operating characteristic (ROC) curves and calculated the area under the curve (AUC) to assess the diagnostic value of TLR2 and TLR4 for distinguishing between patients with CRC and controls. When the AUC was $>0.7$, we applied a cut-off value at $90 \%$ sensitivity. A Kaplan-Meier survival curve was plotted, and the p-value was calculated according to the log-rank test. A Cox proportional hazards model, adjusted for age, stage, and blood vessel invasion, was built to assess the impacts of TLR2 and TLR4 on survival. The results of the Cox model are presented as the hazard ratio (HR) with a 95\% confidence interval (95\% CI). Two-tailed p-values are presented. Analyses were performed with SPSS for windows (IBM Corp. Released 2012. IBM SPSS Statistics for Windows, Version 21.0. IBM Corp., Armonk, NY, USA).

\section{Results}

\section{Serum TLR2 and TLR4 concentrations in patients with colorectal cancer and controls}

The characteristics of the patient and control groups and the features of the tumors are presented in Table 1. Serum TLR4 levels were higher in the control group (mean $1.8 \mathrm{ng} / \mathrm{ml}, \mathrm{SD} 2.2 \mathrm{ng} / \mathrm{ml}$ ) than in the patient group (mean $1.1 \mathrm{ng} / \mathrm{ml}$, SD $1.6 \mathrm{ng} / \mathrm{ml}, \mathrm{p}=0.015$ ). The proportions of subjects with undetectable or low TLR4 levels were similar in the CRC $(15.5 \% ; 18 / 118)$ and control $(10.2 \% ; 9 / 88 ; p=0.30)$ groups. When only cases with detectable TLR4 concentrations were compared, the difference between the control and patient groups remained significant (respectively, means: $2.0 \mathrm{ng} / \mathrm{ml}$, SD $2.3 \mathrm{ng} / \mathrm{ml}$ vs. $1.3 \mathrm{ng} / \mathrm{ml}$, SD $1.6 \mathrm{ng} / \mathrm{ml}$; medians: $1.0 \mathrm{ng} / \mathrm{ml}$ vs. $0.9 \mathrm{ng} / \mathrm{ml} ; \mathrm{p}=0.026$ ). The ROC-curve AUCs (all patients: $0.587,95 \%$ CI: $0.508-0.666$ and patients with TLR4 $>0: 0.580,95 \%$ CI: $0.495-0.664)$ failed to reach the 0.7 threshold, which was the cutoff for a significant effect. The control group was sampled in winter, when the risk of flu is high; thus, the presence of infection could have contributed to the higher TLR4 values observed in the control group compared to the patient group. To test for this possibility, we compared serum TLR4 values between controls and patients that underwent operations during the flu season (October - March; $n=44$ ); we found that, although the trend remained the same, the difference was no longer statistically significant (controls: $1.8 \mathrm{ng} / \mathrm{ml}, \mathrm{SD} 2.2 \mathrm{ng} / \mathrm{ml}$ vs. patients: $1.3 \mathrm{ng} / \mathrm{ml}, \mathrm{SD}$ $1.9 \mathrm{ng} / \mathrm{ml} ; \mathrm{p}=0.230$ ). However, the percentage of patients with undetectable serum TLR4 was similar, regardless 
of whether the operation was performed in winter or in other seasons (winter: $13.6 \%$ vs. other: $16.7 \%$; $\mathrm{p}=0.794$ ). Female patients had higher serum TLR4 concentrations than male patients (Table 2).

The serum TRL2 concentrations were not significantly different between patient and control groups, but $74.9 \%$ $(152 / 203)$ of all subjects had undetectable TRL2 values. Again, the proportions of subjects with undetectable serum TLR2 were similar between groups (CRC group: 87/115, 75.7\%; controls: 65/88, 73.9\%; p=0.771). When we included only subjects with detectable TLR2 concentrations, we found a weak trend of a higher mean concentration in the control group (mean $4.6 \mathrm{ng} / \mathrm{ml}$, SD $5.8 \mathrm{ng} / \mathrm{ml}$ ) compared to the patient group (mean 2.6 ng/ml, SD $4.5 \mathrm{ng} / \mathrm{ml}$, median $1.4 \mathrm{ng} / \mathrm{ml}$ vs. $0.5 \mathrm{ng} / \mathrm{ml}$; $\mathrm{p}=0.214)$. The ROC curve AUC was 0.692 (95\% CI: 0.544-0.839).

\section{Relationship between lesional and serum TLR2 and TLR4}

As described in a previous study, in carcinoma cells, TLR2 expression was increased and TLR4 expression was reduced compared to levels in normal colorectal epithelium (13). In the present study, we found that serum levels of TLR2 and TLR4 were not correlated with the levels of TLR2 and TLR4 expression in carcinomas or their nodal metastases (based on staining intensity, histoscores, and tumor mass-weighted histoscores; data not shown). However, patients with measurable serum TLR2 had higher TLR2 expression in normal mucosa (median histoscore 195, 95\% CI: 125-185) compared to patients with undetectable serum TLR2 (median histoscore 100, 95\% CI: 107-136; p=0.034). In contrast, no association was found between serum TLR4 concentrations and TLR4 expression levels in normal mucosa.

\section{Serum TLR2 and TLR4 concentrations and clinicopathological features of carcinomas}

The frequency of undetectable serum TLR4 was higher in patients with TNM stage I disease compared to patients in more advanced stages or the control group (Table 3). Additionally, the serum TLR4 concentration was significantly lower among patients in stage I (mean $0.6 \mathrm{ng} / \mathrm{ml}$, SD $0.9 \mathrm{ng} / \mathrm{ml}$ ) than among the controls (mean $1.8 \mathrm{ng} / \mathrm{ml}, \mathrm{SD} 2.2 \mathrm{ng} / \mathrm{ml}$; $\mathrm{p}<0.001$ ). To test the impact of sampling the control group in winter, we compared the control group to patients in stage I that had received operations during the flu season $(n=7)$. We found an even greater difference between groups (controls: $0.5 \mathrm{ng} / \mathrm{ml}, \mathrm{SD} 0.6 \mathrm{ng} / \mathrm{ml} \mathrm{vs}$, patients: $1.8 \mathrm{ng} / \mathrm{ml} \mathrm{SD}$ $2.2 \mathrm{ng} / \mathrm{ml} ; \mathrm{p}<0.001)$. However, the mean TLR4 values between patients in stage I and other patients were not significantly different (stage I: mean $0.6 \mathrm{ng} / \mathrm{ml}, \mathrm{SD} 0.9$ vs. other stages: mean $1.2 \mathrm{ng} / \mathrm{ml}, \mathrm{SD} 1.7 \mathrm{ng} / \mathrm{ml}$;

This article is protected by copyright. All rights reserved. 
$\mathrm{p}=0.143$ ). Moreover, although the difference was even greater for patients sampled in the flu season (stage I: 0.5 $\mathrm{ng} / \mathrm{ml}$, SD $0.6 \mathrm{ng} / \mathrm{ml}$ and other stages: $1.5 \mathrm{ng} / \mathrm{ml}, \mathrm{SD} 2.0 \mathrm{ng} / \mathrm{ml}$ ), it failed to reach statistical significance $(\mathrm{p}=0.188)$. Blood vessel invasion was strongly associated with undetectable serum TLR2 (Table 2). The majority $(95.7 \%$; 22/23) of patients with blood vessel invasion had undetectable serum TLR2; only one of these patients had measurable serum TLR2 $(4.3 \%, 1 / 23 ; \mathrm{p}=0.013)$.

In groups of high or low serum TLR2 concentrations, we found no differences in TNM stage distributions. Moreover, the cancer grade was not associated with the TLR2 serum concentration. The variation in TRL4 serum concentration across tumor grades was uninterpretable, because TRL4 concentrations were higher in Grade 2 than in both Grade 1 and Grade 3 (Table 2).

\section{Serum TLR2 and TLR4 and the systemic inflammatory response}

CRP concentrations were higher in patients with undetectable serum TLR2 concentrations (mean CRP: 13.9 $\mathrm{mg} / \mathrm{l}, \mathrm{SD} 31.3 \mathrm{mg} / \mathrm{l}$ ) than in patients with measurable serum TLR2 (mean CRP: $5.1 \mathrm{mg} / \mathrm{l}, \mathrm{SD} 6.6 \mathrm{mg} / \mathrm{l} ; \mathrm{p}=0.013$ ). Similarly, serum CRP tended to be higher in patients with undetectable serum TLR4 (mean CRP: $12.6 \mathrm{mg} / \mathrm{l}$, SD $29.6 \mathrm{mg} / \mathrm{l}$ ) compared to patients with measurable TLR4 (mean CRP: $6.0 \mathrm{mg} / \mathrm{l}, \mathrm{SD} 8.3 \mathrm{mg} / \mathrm{l} ; \mathrm{p}=0.064$ ). However, among individuals with measurable serum TLR2 $(n=28)$, those with mGPS scores of 0 had significantly higher TLR2 levels (mean $3.28 \mathrm{ng} / \mathrm{ml}$, SD $4.94 \mathrm{ng} / \mathrm{ml}$ ) than in those with mGPS scores of 1 (mean $0.28 \mathrm{ng} / \mathrm{ml}$, SD 0.22 $\mathrm{ng} / \mathrm{ml} ; \mathrm{p}=0.010$ ). No patients with measurable serum TLR2 had mGPS scores of 2 . Among patients with undetectable serum TLR2, 67 patients (75.3\%) had mGPS scores of 0,16 patients $(72.7 \%)$ had mGPS scores of 1, and 4 patients (100\%) had mGPS scores of 2. Serum TLR4 levels did not correlate with the mGPS scores.

\section{Serum TLR2 and TLR4 levels and survival}

Serum TLR4 was not correlated with either disease-free or overall survival. The 5-year survival rates were 50\% and $61.2 \%$ for patients without and with detectable TLR4, respectively ( $\mathrm{p}=0.437)$. However, a trend suggested that undetectable serum TLR2 was associated with worse overall survival. Patients with undetectable TLR2 had $19.8 \%$ worse 5 -year overall survival than those with measurable TLR2 (55.2\% vs. $75.0 \%$; $\mathrm{p}=0.052$; Figure 1$)$. Moreover, in a Cox model adjusted for stage, age, and blood vessel invasion, patients with undetectable serum TLR2 had an elevated hazard ratio, but it was not statistically significant (HR 1.77, $95 \%$ CI: 0.75 to 4.18 , $\mathrm{p}=0.192$; Table 4). The TLR2 level was not associated with disease-free survival. 


\section{Discussion}

To our knowledge, this study was the first to evaluate serum TLR2 and TLR4 concentrations in CRC. TLR4 levels were reduced in patients with CRC compared to control subjects. In TLR2 assays, undetectable levels were common, but we observed no differences between the patients and controls. However, undetectable or low serum TLR2 concentrations were associated with systemic inflammation, and there was a trend towards an association between low TLR2 and a poor CRC prognosis. The expression of these TLRs in tumor cells was not associated with serum levels. In contrast, high levels of TLR2 expression in normal colorectal mucosa were associated with high serum TLR2 levels. These findings suggested that serum TLR2 levels may reflect TLR2 expression in normal colorectal mucosa, and that TLR2 levels might be inversely associated with systemic inflammation in CRC.

It has been well documented that high CRP and high mGPS are associated with high recurrence rates and worse overall survival in CRC (21-23). We found that the mean CRP concentration and mGPS were higher when the serum TLR2 concentration was low or undetectable. However, the mechanisms underlying these associations remain speculative at present. Growing evidence has suggested that soluble forms of TLR2 might downregulate innate immune activation by sequestering pathogen-associated molecular patterns (PAMPs) and damageassociated molecular patterns (DAMPs). In that scenario, TLR ligands would not be detected by cell-membranebound TLRs (24). Accordingly, when serum levels of TLR2 were low or absent, systemic inflammatory responses might rise, due to elevated levels of free TLR2 ligands with proinflammatory properties. Thus, low serum TLR2 might contribute to aberrant systemic inflammation, but this hypothesis requires further investigation.

Many factors have been shown to affect TLR2 and TLR4 expression in tissues, but factors that affect serum levels are poorly characterized. However, micro-organisms and endogenous ligands released during tissue damage, necrotic cell death, and infection could induce signaling pathways that contribute to serum TLR levels $(25,26)$. In the present study, we found no association between serum TLR2 and TLR4 levels and tumor TLR2 and TLR4 expression; thus, these findings did not support the hypothesis that serum TLR2 and TLR4 levels are significantly defined by tumor TLR expression or tumor mass. In contrast, we found that TLR2 expression in 
normal colorectal mucosa epithelial cells was positively correlated with serum TLR2 concentrations in patients with CRC. However, this correlation was not observed for TLR4.

Although this study was exploratory in nature, and thus, further confirmatory studies are required, the association we found between mucosal and serum TLR2 levels represented the first evidence of a potential link between the intestinal mucosal innate immune response and the serum concentration of a TLR. We recently reported that the presence of a tumor did not modify adjacent human colorectal mucosal expression of TLRs (27). That finding suggested that constitutive luminal factors, such as microbial flora, were more important in the regulation of TLR expression than tumor-related factors. Based on our present finding of a correlation between serum TLR2 levels and TLR2 expression in normal colorectal mucosa, combined with recent evidence that probiotic flora administration could induce TLR2 expression and downregulate inflammation in colon mucosa, we speculate that, in a subset of patients, it might be possible to downregulate systemic inflammation in CRC by modifying the luminal flora (28).

We found that controls had higher serum TLR4 concentrations than patients with CRC, but the difference could be explained at least partly by the effects of the flu season. However, patients with stage 1 CRC had even lower serum TLR4 concentrations than controls during flu season. Mechanisms that give rise to low serum TLR4 levels in stage I CRC remain speculative; however, our results did not support the hypothesis that they might be explained by the observed downregulation of TLR4 in tumor tissues. Although we did not observe an association between serum TLR4 levels and TLR4 expression in normal colorectal mucosa, we could not exclude a contribution from non-neoplastic small intestine mucosa, where variations due to environmental factors are more extensive (29).

Most of the patient group and a majority of the control group had undetectable serum TLR2 levels, but TLR4 could be detected in the majority of subjects. A more sensitive method for measuring serum TLR2 might have provided more information about TLR2 levels and their relationship to CRC features. On the other hand, there could be important physiological differences between TLR2 and TLR4. In normal mucosa, TLR2 staining was weaker than TLR4 staining, as shown in our previous study (13). This difference in physiological tissue expression levels of these receptors, taken together with the correlation between serum TLR2 levels and normal 
colorectal mucosa TLR2 expression, suggested a potential mechanistic link that might explain why serum TLR2 concentrations were undetectable or low more often than serum TLR4 concentrations.

This study had some limitations. First, the small sample size might have limited our statistical power. For example, in the Cox model, the HR for absent serum TLR2 was 1.77, which did not reach statistical significance; indeed, neither did blood vessel invasion (HR 1.65, p=0.16, Table 4), even though its association with survival has been well established. These results require further investigation with a larger patient group. Another limitation was that the method for measuring TLR2 serum level was not sufficiently sensitive, which resulted in many specimens with undetectable TLR2. Additionally, all the blood samples in the control group were collected during winter months, which could have introduced seasonal variation effects on TLR levels, as speculated earlier. Multiple hypotheses were tested in this exploratory study, and therefore, we interpreted findings with caution when p-values were near 0.05 . These results require further validation in independent studies.

In summary, this study was the first to evaluate serum TLR levels in CRC. We found that CRC was characterized by low serum TLR4 levels, but the underlying mechanism remains unclear. We found that undetectable or low serum TLR2 levels in CRC were associated with systemic inflammation, and we observed a trend that suggested an association between low serum TLR2 and a poor prognosis. Moreover, we found an association between normal colorectal mucosal TLR2 expression and serum TLR2 levels, which suggested that normal intestinal mucosa may contribute to serum TLR2 levels. More studies are needed to test the hypothesis that an induced increase in systemic TLR2 levels might downregulate systemic inflammation. We hypothesize that a modification in the intestinal microbiome might induce an intestinal mucosal TLR2 response. Additional studies are required to assess the prognostic value of serum TLR2 and TLR4.

Acknowledgements: The authors would like to thank Erja Tomperi and Riitta Vuento for preparing the immunohistochemical stains.

This work was supported by the Mary and Georg C. Ehrnrooth Foundation through a personal grant awarded to Karoliina Paarnio.

This article is protected by copyright. All rights reserved. 


\section{Compliance with Ethical Standards:}

Conflict of Interest: The authors declare no conflict of interest.

Ethical approval: All procedures performed in this study involving human participants were in accordance with the ethical standards of the institutional and/or national research committee and with the 1964 Helsinki declaration and its later amendments or comparable ethical standards.

Informed consent: Informed consent was obtained from all individual participants included in the study.

\section{References}

1. Steliarova-Foucher E, O’Callaghan M, Ferlay J, Masuyer E, Forman D, Comber H, et al. European Cancer Observatory: Cancer Incidence, Mortality, Prevalence and Survival in Europe. Version 1.0 (September 2012) European Network of Cancer Registries, International Agency for Research on Cancer. Available from http://eco.iarc.fr, accessed on 1/12/2016

2. American Cancer Society (2017) Cancer Facts \& Figures 2017. Atlanta: American Cancer Society, $2017: 10$

3. Cunningham D, Atkin W, Lenz HJ, Lynch HT, Minsky B, Nordlinger B et al. Colorectal cancer. Lancet 2010;375(9719):1030-1047; PMID: 20304247; DOI: 10.1016/S0140-6736(10)60353-4

4. Ogino S, Nishihara R, VanderWeele TJ, Wang M, Nishi A, Lochhead P, et al. The Role of Molecular Pathological Epidemiology in the Study of Neoplastic and Non-Neoplastic Diseases in the Era of Precision Medicine. Epidemiology 2016;27(4):602-611; PMID: 26928707; DOI: 10.1097/EDE.0000000000000471

5. Colotta F, Allavena P, Sica A, Garlanda C, Mantovani A. Cancer-related inflammation, the seventh hallmark of cancer: links to genetic instability. Carcinogenesis 2009;30(7):1073-1081; PMID: 19468060; DOI: $10.1093 /$ carcin/bgp127

6. Klintrup K, Makinen JM, Kauppila S, Vare PO, Melkko J, Tuominen H, et al. Inflammation and prognosis in colorectal cancer. Eur J Cancer 2005;41(17):2645-2654; PMID: 16239109; DOI: 10.1016/j.ejca.2005.07.017

7. Väyrynen JP, Kantola T, Väyrynen SA, Klintrup K, Bloigu R, Karhu T et al. The relationships between serum cytokine levels and tumor infiltrating immune cells and their clinical significance in colorectal cancer. Int J Cancer 2016;139:112-21; PMID: 26874795; DOI: 10.1002/ijc.30040.

8. Kantola T, Klintrup K, Vayrynen JP, Vornanen J, Bloigu R, Karhu T, et al. Stage-dependent alterations of the serum cytokine pattern in colorectal carcinoma. Br J Cancer 2012;107(10):1729-1736; PMID: 23059742; DOI: 10.1038/bjc.2012.456

9. Ishizuka M, Nagata H, Takagi K, Horie T, Kubota K. Inflammation-based prognostic score is a novel predictor of postoperative outcome in patients with colorectal cancer. Ann Surg 2007;246(6):1047-1051; PMID: 18043109; DOI: 10.1097/SLA.0b013e3181454171

10. Suzuki Y, Okabayashi K, Hasegawa H, Tsuruta M, Shigeta K, Kondo T, et al. Comparison of Preoperative Inflammation-based Prognostic Scores in Patients With Colorectal Cancer. Ann Surg 2016; PMID: 27984214; DOI: $10.1097 /$ SLA.0000000000002115 
11. Shibolet O, Podolsky DK. TLRs in the Gut. IV. Negative regulation of Toll-like receptors and intestinal homeostasis: addition by subtraction. Am J Physiol Gastrointest Liver Physiol 2007;292(6):G1469-73; PMID: 17554134, DOI: 10.1152/ajpgi.00531.2006

12. Drexler SK, Foxwell BM. The role of toll-like receptors in chronic inflammation. Int J Biochem Cell Biol 2010;42(4):506-518; PMID: 19837184; DOI: 10.1016/j.biocel.2009.10.009

13. Paarnio K, Vayrynen S, Klintrup K, Ohtonen P, Makinen MJ, Makela J, et al. Divergent expression of bacterial wall sensing TLR2 and TLR4 in colorectal cancer. World J Gastroenterol 2017; 23(26): 4831-4838; PMID: 28765705; DOI: 10.3748/wjg.v23.i26.4831

14. Ten Oever J, Kox M, van de Veerdonk FL, Mothapo KM, Slavcovici A, Jansen TL, et al. The discriminative capacity of soluble Toll-like receptor (sTLR) 2 and sTLR4 in inflammatory diseases. BMC Immunol 2014;15:55-014-0055-y; PMID: 25406630; DOI: 10.1186/s12865-014-0055-y

15. Karki K, Pande D, Negi R, Khanna S, Khanna RS, Khanna HD. Correlation of serum toll like receptor 9 and trace elements with lipid peroxidation in the patients of breast diseases. J Trace Elem Med Biol 2015;30:11-16; PID: 25744504; DOI: 10.1016/j.jtemb.2014.12.003

16. Wei F, Yang F, Li J, Zheng Y, Yu W, Yang L, et al. Soluble Toll-like receptor 4 is a potential serum biomarker in non-small cell lung cancer. Oncotarget 2016;7(26):40106-40114; PMID: 27223258; DOI: 10.18632/oncotarget.9496

17. Edited by Sobin L, Gospodarowicz M, Wittekind C. TNM Classification of Malignant Tumours, WileyBlackwell, 2009.

18. Edited by Bosman FT, Carneiro F, Hruban RH, Theise ND. WHO Classification of Tumours of the Digestive System, WHO Press, 2010.

19. Tuppurainen K, Makinen JM, Junttila O, Liakka A, Kyllonen AP, Tuominen H, et al. Morphology and microsatellite instability in sporadic serrated and non-serrated colorectal cancer. J Pathol 2005;207(3):285-294; PMID: 16177963, DOI: 10.1002/path.1850 [doi]

20. Vayrynen SA, Vayrynen JP, Klintrup K, Makela J, Karttunen TJ, Tuomisto A, et al. Clinical impact and network of determinants of tumour necrosis in colorectal cancer. Br J Cancer 2016;114(12):1334-1342; PMID: 27195424; DOI: 10.1038/bjc.2016.128

21. McMillan DC, Wotherspoon HA, Fearon KC, Sturgeon C, Cooke TG, McArdle CS. A prospective study of tumor recurrence and the acute-phase response after apparently curative colorectal cancer surgery. Am J Surg 1995;170(4):319-322;PMID: 27033063; DOI: 10.1007/s12253-016-0056-7

22. Karadima ML, Saetta AA, Chatziandreou I, Lazaris AC, Patsouris E, Tsavaris N. The Prognostic Influence of BRAF Mutation and other Molecular, Clinical and Laboratory Parameters in Stage IV Colorectal Cancer. Pathol Oncol Res 2016; PMID: 27033063; DOI: 10.1007/s12253-016-0056-7

23. Casadei Gardini A, Carloni S, Scarpi E, Maltoni P, Dorizzi RM, Passardi A, et al. Prognostic role of serum concentrations of high-sensitivity C-reactive protein in patients with metastatic colorectal cancer: results from the ITACa trial. Oncotarget 2016;7(9):10193-10202; PMID: 26848624; DOI: 10.18632/oncotarget.7166

24. Henrick BM, Yao XD, Taha AY, German JB, Rosenthal KL. Insights into Soluble Toll-Like Receptor 2 as a Downregulator of Virally Induced Inflammation. Front Immunol 2016;7:291; PMID: 27531999; DOI: 10.3389/fimmu.2016.00291

25. Medzhitov R. Toll-like receptors and innate immunity. Nat Rev Immunol 2001;1(2):135-145; PMID: 11905821; DOI: $10.1038 / 35100529$

26. Awla D, Abdulla A, Regner S, Thorlacius H. TLR4 but not TLR2 regulates inflammation and tissue damage in acute pancreatitis induced by retrograde infusion of taurocholate. Inflamm Res 2011;60(12):1093-1098;

PMID: 21863370; DOI: 10.1007/s00011-011-0370-1 
27. Huhta H, Helminen O, Kauppila JH, Salo T, Porvari K, Saarnio J, et al. The Expression of Toll-like Receptors in Normal Human and Murine Gastrointestinal Organs and the Effect of Microbiome and Cancer. J Histochem Cytochem 2016;64(8):470-482; PMID: 27370795; DOI: 10.1369/0022155416656154

28. Kuugbee ED, Shang X, Gamallat Y, Bamba D, Awadasseid A, Suliman MA, et al. Structural Change in Microbiota by a Probiotic Cocktail Enhances the Gut Barrier and Reduces Cancer via TLR2 Signaling in a Rat Model of Colon Cancer. Dig Dis Sci 2016;61(10):2908-2920; PMID: 27384052; DOI: 10.1007/s10620-0164238-7

29. Dlugosz A, Zakikhany K, Acevedo N, D'Amato M, Lindberg G. Increased Expression of Toll-Like Receptors 4, 5, and 9 in Small Bowel Mucosa from Patients with Irritable Bowel Syndrome. Biomed Res Int 2017;2017:9624702; PMID: 28246611; DOI: 10.1155/2017/9624702

This article is protected by copyright. All rights reserved. 


\section{Tables}

Table 1. Characteristics of 118 patients with colorectal carcinoma and 88 controls. Survival data applies to the patient group.

Characteristic

Patients, n $(\%)$

Survival at 5-year

Controls, n $(\%)$ follow-up, n (\%)

Gender

Male $56(47.5)$

Female $62(52.5)$

$35(62.5)$

$36(58.1)$

$46(52.3)$

$69(36-89)$

$67(60-74)$

$42(47.7)$

Age, median (range)

$69(36-89)$

$67(46-87)$

Type of operation

$\begin{array}{rcc}\text { Radical }^{1} & 94(80.3) & 69(73.4) \\ \text { Palliative }^{2} & 23(19.7) & 2(8.7)\end{array}$

Location of tumor

$\begin{array}{rcc}\text { Proximal colon } & 46(39.0) & 27(58.7) \\ \text { Distal colon } & 39(33.1) & 25(64.1) \\ \text { Rectum } & 32(27.1) & 18(56.3) \\ \text { Multiple tumors } & 1(0.8) & 1(100.0)\end{array}$

Modified Glasgow prognostic score

$\begin{array}{rcr}0 & 90(76.3) & 62(68.9) \\ 1 & 22(18.6) & 6(27.3) \\ 2 & 4(3.4) & 1(25.0)\end{array}$

Data missing $2(1.7)$

Stage

$\begin{array}{rcr}\text { I } & 18(15.3) & 15(83.3) \\ \text { II } & 48(40.7) & 37(77.1) \\ \text { III } & 30(25.4) & 16(53.3) \\ \text { IV } & 22(18.6) & 3(13.6)\end{array}$

Grade

$\begin{array}{rcc}\text { I } & 17(14.4) & 13(76.5) \\ \text { II } & 86(72.9) & 53(61.6) \\ \text { III } & 14(11.9) & 5(35.7) \\ \text { Data missing } & 1(0.8) & 0(0)\end{array}$

Lymph node metastasis

$$
\begin{array}{rrr}
\text { No } & 72(61.0) & 53(73.6) \\
\text { Yes } & 46(39.0) & 18(39.1)
\end{array}
$$

Blood vessel invasion

\begin{tabular}{|c|c|c|c|}
\hline $\begin{array}{r}\text { Serum TLR2 ng/ml, mean (SD) } \\
\text { median (IQR) }\end{array}$ & $\begin{array}{l}0.6(2.5) \\
0.0(0.0 .)\end{array}$ & $\begin{array}{l}1.0(3.1) \\
0.0(0.1)\end{array}$ & $\begin{array}{l}1.1(3.5) \\
0.0(0.1)\end{array}$ \\
\hline $\begin{array}{r}\text { Serum TLR4 ng/ml, mean (SD) } \\
\text { median (IQR) }\end{array}$ & $\begin{array}{l}1.1(1.6) \\
0.6(1.4)\end{array}$ & $\begin{array}{l}1.2(1.6) \\
0.7(1.3)\end{array}$ & $\begin{array}{l}1.8(2.2) \\
0.9(1.8)\end{array}$ \\
\hline
\end{tabular}

$\begin{array}{rcr}\text { No } & 91(77.1) & 61(67.0) \\ \text { Yes } & 23(19.5) & 8(34.8) \\ \text { Data missing } & 4(3.4) & \end{array}$

This article is protected by copyright. All rights reserved. 
Values are the number (\%) of individuals in each group, unless otherwise specified.

${ }^{1}$ One patient underwent radical surgery for distant metastases in a second operation

${ }^{2}$ Metastases were treated non-operatively in two patients (both alive at the 5-year follow-up)

${ }^{3}$ No significant difference in serum TLR2 between patients and controls, $p=0.251$

${ }^{4}$ Significant difference in serum TLR4 between patients and controls, $\mathrm{p}=0.015$

Table 2. Serum TLR2 and TLR 4 concentrations (mean and median) and clinicopathological features of patients with colorectal carcinoma

\begin{tabular}{|c|c|c|c|c|}
\hline Variable & $\begin{array}{c}\text { Serum TLR2 (ng/ml), } \\
\text { Mean (SD) / Median } \\
(\text { IQR) }\end{array}$ & $P$ value & $\begin{array}{c}\text { Serum TLR4 (ng/ml), } \\
\text { Mean (SD) / Median } \\
(\mathrm{IQR})\end{array}$ & $P$ value \\
\hline All Patients & $0.6(2.5) / 0.0(0.0)$ & & $1.1(1.6) / 0.6(1.4)$ & \\
\hline \multicolumn{5}{|l|}{ Age } \\
\hline$\leq 75(\mathrm{n}=84)$ & $0.8(2.9) / 0.0(0.0)$ & 0.86 & $1.1(1.4) / 0.5(1.4)$ & 0.66 \\
\hline$>75(\mathrm{n}=31)$ & $0.1(0.3) / 0.0(0.02)$ & & $1.2(2.1) / 0.6(1.4)$ & \\
\hline \multicolumn{5}{|l|}{ Sex } \\
\hline Male $(n=56)$ & $0.7(2.2) / 0.0(0.0)$ & 0.41 & $0.8(1.1) / 0.4(1.4)$ & 0.048 \\
\hline Female $(\mathrm{n}=62)$ & $0.6(2.7) / 0.0(0.08)$ & & $1.4(1.9) / 0.9(1.5)$ & \\
\hline \multicolumn{5}{|l|}{ BMI } \\
\hline$<25(\mathrm{n}=47)$ & $0.4(1.5) / 0.0(0.0)$ & 0.45 & $0.9(1.4) / 0.4(1.2)$ & 0.28 \\
\hline $25-30(n=46)$ & $1.0(3.1) / 0.0(0.1)$ & & $1.4(1.9) / 1.0(1.4)$ & \\
\hline$>30(\mathrm{n}=23)$ & $0.6(2.9) / 0.0(0.0)$ & & $1.1(1.1) / 0.7(1.4)$ & \\
\hline \multicolumn{5}{|l|}{ Location of tumor* } \\
\hline Proximal colon $(n=46)$ & $0.7(2.9) / 0.0(0.1)$ & 0.68 & $1.2(1.4) / 1.0(1.2)$ & 0.061 \\
\hline Distal colon $(n=39)$ & $0.6(2.4) / 0.0(0.0)$ & & $1.2(2.0) / 0.5(1.4)$ & \\
\hline Rectum (n=32) & $0.6(1.9) / 0.0(0.0)$ & & $1.0(1.3) / 0.3(1.6)$ & \\
\hline \multicolumn{5}{|l|}{ WHO grade } \\
\hline Grade $1(n=17)$ & $0.9(2.6) / 0.0(0.2)$ & 0.97 & $0.4(0.4) / 0.3(0.6)$ & 0.035 \\
\hline Grade $2(n=86)$ & $0.4(1.8) / 0.0(0.008)$ & & $1.3(1.8) / 0.8(1.5)$ & \\
\hline Grade $3(n=14)$ & $1.6(5.2) / 0.0(0.3)$ & & $0.8(0.6) / 0.6(0.9)$ & \\
\hline \multicolumn{5}{|l|}{ TNM Stage } \\
\hline Stage I $(n=18)$ & $1.2(2.9) / 0.0(0.7)$ & 0.96 & $0.6(0.9) / 0.3(1.2)$ & 0.17 \\
\hline Stage II $(n=48)$ & $1.0(3.4) / 0.0(0.0)$ & & $1.1(1.4) / 0.6(1.3)$ & \\
\hline Stage III $n=30$ ) & $0.06(0.1) / 0.0(0.04)$ & & $1.7(2.3) / 0.9(1.7)$ & \\
\hline Stage IV $(n=22)$ & $0.2(0.6) / 0.0(0.09)$ & & $0.9(1.1) / 0.6(1.4)$ & \\
\hline \multicolumn{5}{|l|}{ Primary tumor } \\
\hline $\mathrm{T} 1(\mathrm{n}=4)$ & $-/-$ & 0.37 & $0.5(0.4) / 0.4(0.8)$ & 0.45 \\
\hline $\mathrm{T} 2(\mathrm{n}=19)$ & $1.2(2.9) / 0.0(0.2)$ & & $1.2(2.1) / 0.3(1.8)$ & \\
\hline $\mathrm{T} 3(\mathrm{n}=85)$ & $0.6(2.6) / 0.0(0.0)$ & & $1.2(1.5) / 0.7(1.3)$ & \\
\hline $\mathrm{T} 4(\mathrm{n}=9)$ & $0.1(0.3) / 0.0(0.3)$ & & $1.0(1.1) / 0.4(2.2)$ & \\
\hline \multicolumn{5}{|l|}{ Lymph node metastasis } \\
\hline N0 $(n=70)$ & $1.0(3.2) / 0.0(0.01)$ & 0.72 & $1.0(1.3) / 0.5(1.3)$ & 0.62 \\
\hline N1 $(n=27)$ & $0.2(0.6) / 0.0(0.08)$ & & $1.5(2.3) / 0.8(1.4)$ & \\
\hline $\mathrm{N} 2(\mathrm{n}=19)$ & $0.1(0.2) / 0.0(0.0)$ & & $1.4(1.4) / 0.9(1.9)$ & \\
\hline
\end{tabular}

Distant Metastasis

This article is protected by copyright. All rights reserved. 


\begin{tabular}{|c|c|c|c|c|}
\hline M0 (n=96) & $0.7(2.7) / 0.0(0.004)$ & 0.93 & $1.2(1.7) / 0.5(1.4)$ & 0.80 \\
\hline M1 (n=22) & $0.2(0.6) / 0.0(0.09)$ & & $0.9(1.1) / 0.6(1.4)$ & \\
\hline \multicolumn{5}{|c|}{ Lymphatic invasion } \\
\hline No $(n=72)$ & $1.0(3.2) / 0.0(0.04)$ & 0.50 & $1.1(1.7) / 0.5(1.4)$ & 0.36 \\
\hline Yes $(n=46)$ & $0.2(0.8) / 0.0(0.0)$ & & $1.2(1.5) / 0.6(1.3)$ & \\
\hline \multicolumn{5}{|c|}{ Blood vessel invasion } \\
\hline No $(n=91)$ & $0.8(2.8) / 0.0(0.09)$ & 0.015 & $1.1(1.5) / 0.5(1.3)$ & 0.36 \\
\hline Yes $(n=23)$ & $0.02(0.1) / 0.0(0.0)$ & & $1.5(1.9) / 0.9(1.6)$ & \\
\hline \multicolumn{5}{|c|}{$\begin{array}{l}\text { Modified Glasgow } \\
\text { Prognostic Score (mGPS) }\end{array}$} \\
\hline $0(\mathrm{n}=90)$ & $0.8(2.8) / 0.0(0.008)$ & 0.53 & $1.2(1.5) / 0.8(1.4)$ & 0.38 \\
\hline $1(n=22)$ & $0.08(0.2) / 0.0(0.07)$ & & $0.9(1.8) / 0.6(0.8)$ & \\
\hline $2(n=4)$ & $-/-$ & & $0.8(0.5) / 0.8(1.0)$ & \\
\hline
\end{tabular}

*One case with multiple tumors was not included

Note that the $\mathrm{N}$ varies, due to missing samples

Table 3. Serum TLR4 detection in different TNM stages of colorectal carcinoma

\begin{tabular}{lccc} 
Disease status & $\begin{array}{c}\text { TLR4 }=0 \\
\text { (undetectable }) \\
\mathrm{n}(\%)\end{array}$ & $\begin{array}{c}\text { TLR4 }>0 \\
\text { detectable) } \\
\mathrm{n}(\%)\end{array}$ & $\begin{array}{c}\text { p-value } \\
\text { (vs. TNM stage I) }\end{array}$ \\
TNM Stage I & $7(38.9)$ & $11(61.1)$ & \\
TNM Stage II-IV & $11(11.2)$ & $87(88.8)$ & 0.008 \\
Control group & $9(10.2)$ & $79(89.8)$ & 0.006 \\
\hline
\end{tabular}

This article is protected by copyright. All rights reserved. 
Table 4. Results from a multivariate Cox model for testing the impact of TLR2 on 5-year survival; age, stage, and blood vessel invasion are adjustment factors.

\begin{tabular}{lccccc} 
Contributing factors & $\mathrm{N}$ & Univariate HR & $\mathrm{HR}^{1}$ & $95 \% \mathrm{CI}$ & $\mathrm{p}$-value \\
\hline Age, $>$ 75-y & 31 & 1.63 & 1.63 & 0.87 to 3.08 & 0.12 \\
Stage III/IV & 52 & 4.09 & 3.54 & 1.81 to 6.90 & $<0.001$ \\
Blood vessel invasion & 23 & 3.09 & 1.65 & 0.83 to 3.28 & 0.16 \\
Serum TLR2 $>0$ & 27 & 2.16 & 1.77 & 0.75 to 4.18 & 0.19 \\
\hline
\end{tabular}

HR: Hazard ratio; 95\% CI: 95\% confidence interval

This article is protected by copyright. All rights reserved. 


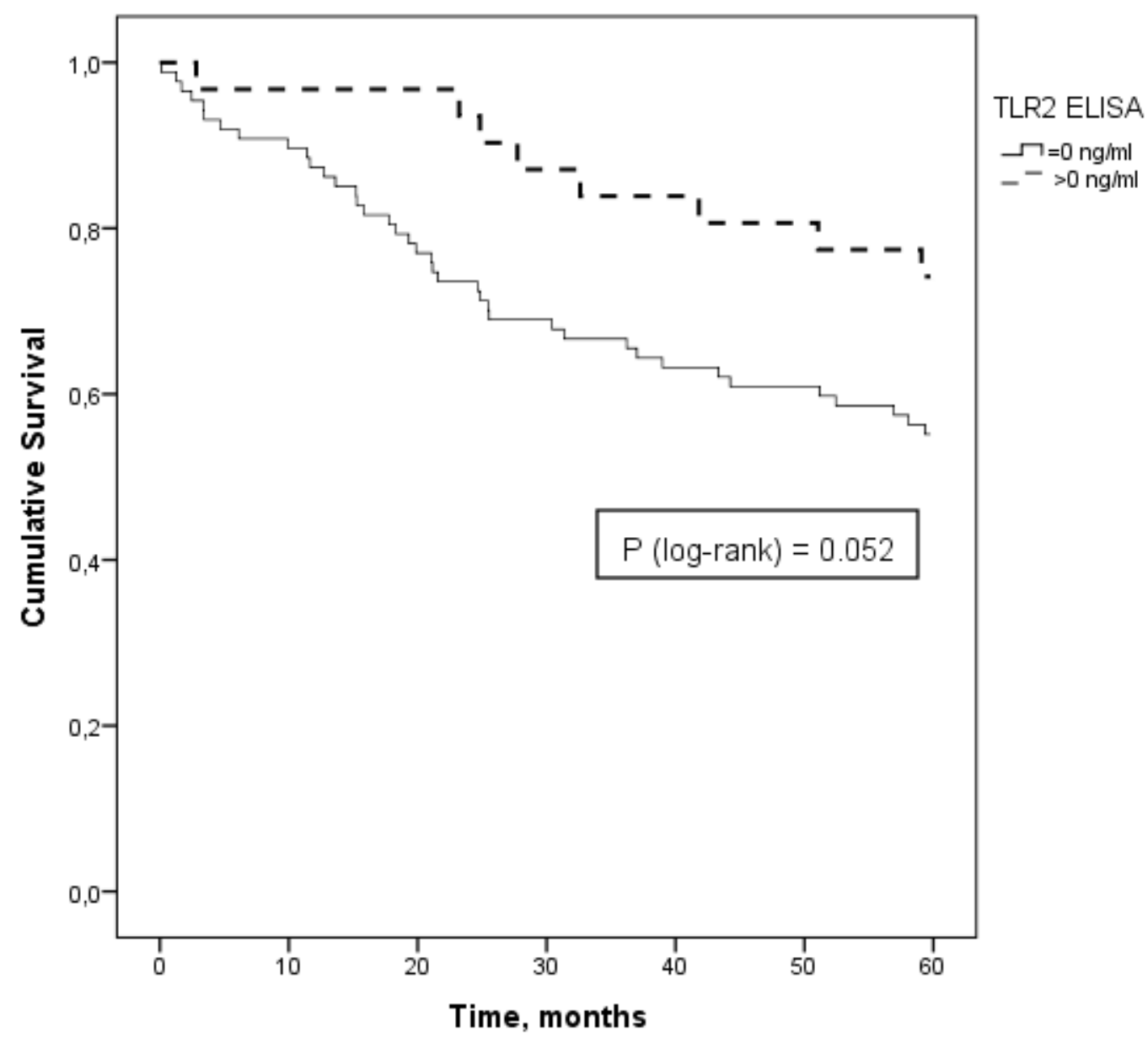

Fig. 1 Kaplan-Meier curves show overall survival in patients with colorectal cancer with different serum TLR2 concentrations. Patients with undetectable serum TLR2 (solid line, TLR2=0; $n=87$ ) are compared to patients with measurable serum TLR2 (dotted line; TLR2 >0; $n=27$ ).

This article is protected by copyright. All rights reserved. 